\title{
Determinants of Capital Inflows: Evidence from Sri Lanka
}

\author{
Erandi Liyanage ${ }^{1}$
}

\begin{abstract}
This paper investigates the causes of capital flows into Sri Lanka in the form of push and pull factors, using the Fully Modified Ordinary Least Square (FMOLS) approach and the Vector Error Correction Model (VECM) for the period from 2001Q1 to 2015Q2. The study consists of four specifications that employ total capital inflows as a dependent variable and disaggregate the total capital inflows to main three categories. Based on empirical estimates, this study observes that capital flows get attracted largely due to pull factors such as real GDP, interest rate and political stability. The study also establishes that the fundamental causes of capital flows in disaggregate levels differ. These results suggest that Sri Lanka needs to pay close attention to keep domestic macroeconomic variables in the right order in order to attract foreign capitals.
\end{abstract}

Key Words: Capital inflows, Pull factors, Push factors, Fully Modified Ordinary Least Square approach, Vector Error Correction Model

JEL Classification: $C 23, F 21, F 32$

\footnotetext{
${ }^{1}$ The author wishes to thank Mrs. Swarna Gunaratne, Mr. Mahinda Siriwardena, Dr. Yuthika Indraratne, Mr. D Kumaratunga, Mrs. K N N M Bandara, Dr. Roshan Perera, Mrs. Dimuthu Samaratunga, Mr. D L Nihal, Dr. Chandranath Amarasekara, Dr. P K G Harischandra, Dr. Hemantha Ekanayake, Dr. Sumila Wanaguru, Dr. Anil Perera and Mr. Sumudu Gunaratne of Central Bank of Sri Lanka and Dr. Ole Rummel of Bank of England for the encouragement and valuable comments. The author is also thankful to anonymous reviewers.erah@cbsl.lk, erandi_hasi@yahoo.com
} 


\section{Introduction}

Capital flows are one of the key sources of funds for developing countries and are important to sustain economic development. Although inflows ${ }^{2}$ of foreign capital can supply the needed capital to support economic development, it can also have an adverse impact on the economy and financial system of the recipient countries if the capital inflows are not properly managed (Yu, 2009). Given the importance of capital flows to an economy, it has received great attention from developing countries in recent decades.

Countries with economic stability and favourable environments for investment attract huge capital flows, augmenting their economic growth and development (Jabbar and Awan, 2014). During the past decade, most of the countries in the South Asian Association for Regional Cooperation (SAARC) region received massive capital inflows due to their rapid economic development and steady export performance (Yu, 2009). In a similar vein, Sri Lanka, which is a small open economy has also attracted capital flows in pursuing its development agenda. With the partial liberalisation of the capital account in Sri Lanka in 2001, the country has benefited from the surge of capital flow. Capital flows into a country can be influenced by many factors. These include economic, social and political developments in both capital exporting as well as importing countries, and could be broadly divided into two major categories; push factors (external factors) and pull factors (internal factors). Push factors are related to the economic cycle and other developments in capital exporting countries, which include changes in world interest rates, changes in the financial systems of capital exporting countries, world growth and the demographic structure of industrialised countries. Pull factors are related to the reforms and future economic growth prospects and other developments, especially in the macroeconomic front in capital importing countries, which include increase in productivity and growth prospects in capital importing countries, domestic financial market reforms, trade and capital market liberalisation and government policies on taxation and foreign investment, flexibility of the labour market and wage structures, as well as domestic interest rates in capital importing countries.

Understanding the determinants of capital inflows is a key concern, since it may have crucial impacts on developing countries like Sri Lanka and its policy implications. Therefore, this paper attempts to investigate the determinants of capital flows into

\footnotetext{
${ }^{2}$ The balance of payment (BOP), reflecting a country's capital flows and trade, consists of three parts: current account, capital account and financial account. Capital flows are generally captured under the financial accounts of BOP after the revision by the IMF, and represent the amount and direction of capital flows into and out of a country.
} 
Sri Lanka since 2001 in relation to the pull and push factors approach. The key factor to select this time period is that the foreign exchange market liberalised in 2001 by allowing commercial banks to determine the exchange rate (independent float).

This study, however, differs from the existing literature on this subject in the following ways. A probe into determinants of capital flows requires explicit examination of the most relevant set of variables that may relate meaningfully to capital flows. Firstly, this study attempts to examine the determinants of capital flows into Sri Lanka by considering the most important variables such as gross domestic products (GDP) and interest rates, which are commonly known as determinants of capital flows. Existing studies on Sri Lanka do not consider the effects on capital flows via other variables such as private sector credit growth, as well as the effect of the internal conflict which had so long prevailed till 2009. Secondly, previous studies use annual data, but this study employs quarterly data in order to capture the dynamics of variables that could be omitted when using annual time series data. Finally, in addition to analysing total capital flows, a clear distinction was drawn between the three different categories of capital flows, since the literature on capital flows notes that FDI, portfolio investment and other inflows have different drivers.

The remainder of the paper is organised as follows: Section 2 presents a literature review of both the theoretical background and empirical studies. In Section 3, trends and composition of capital flows in to Sri Lanka are discussed including government policies on capital flows. Section 4 describes the methodology, while section 5 presents empirical results. Section 6 discusses the findings, followed by the conclusion and policy recommendations in Section 7.

\section{Literature Review}

\subsection{Determinants of Capital Inflows - Theoretical Background}

Capital inflows include foreign direct investment (FDI), portfolio investment and other investment i.e., government long-term loans and private sector long-term loans. FDI occurs when a non-resident acquires a stake of at least 10 per cent in a domestic enterprise, while portfolio investment includes purchases of securities and equity shareholdings (Rummel, 2014). As the most stable form of capital, FDI is generally assumed to be a stabilising factor during episodes of financial crises in emerging market countries. The theory, as well as empirics of the analysis of capital flows, finds that industrial countries are largely benefited from capital flows. Capital flows allow recipient countries to augment domestic savings by tapping into foreign savings, lowering the cost of capital for borrowers, enabling smooth consumption, helping the development of financial markets and institutions and facilitating the transfer of 
technology and management expertise. At the same time, capital flows allow source countries to improve rates of return available to savers and allow diversification of portfolios (Rummel, 2014).

There are many theories which attempt to explain the determinants of capital flows. According to standard Neoclassical theory, capital flows are driven by return differentials among countries. If there are no restrictions, capital will flow where returns are higher and capital is relatively scarcer, i.e., to developing countries. The second key theory is based on the Capital Asset Pricing Model (CAPM). When securities from different countries show low levels of correlations, investing in foreign assets improves the efficiency of a portfolio, by reducing its overall variance. An implication of the CAPM is that if all investors followed such a strategy, all portfolios in the world should be expected to converge to a standard perfectly diversified world portfolio of international assets (Bonizzi, 2013).

Considering only FDI flows, FDI can take place concurrently in several locations. The reasons for this are explained by the Ownership, Location and Internalisation (OLI) paradigm developed by John Dunning (Mathema, 2004). The paradigm is a blend of three different theories of FDI $=\mathrm{O}+\mathrm{L}+\mathrm{I}$, each piece focusing on a different question. In the OLI framework, 'O' (ownership advantages) hypothesises that the multinational enterprise has one or more firm specific advantage, which allows it to overcome the costs of operating in a foreign country. The locational advantages ' $L$ ' (country specific advantages) explain why certain locations are selected to host the subsidiary operations of multinational companies (MNCs). The selection of investment location depends upon a complex calculation that includes economic, social and political factors. Finally, the 'I' factor means international advantage (Mathema, 2004).

As shown in Figure 1, low-income developing countries have integrated significantly with global financial markets over the past few decades, with annual gross private capital inflows increasing to 6.4 percent of GDP in 2013. Low-income developing countries are typically more credit constrained than advanced economies, and capital inflows can be an important source of financial deepening for these economies to stimulate investment and efficient allocation of resources (IMF, 2015). 


\section{Figure 1: Gross Capital Inflows and Private Credit in Selected Low Income Developing Countries (Per cent of GDP)}

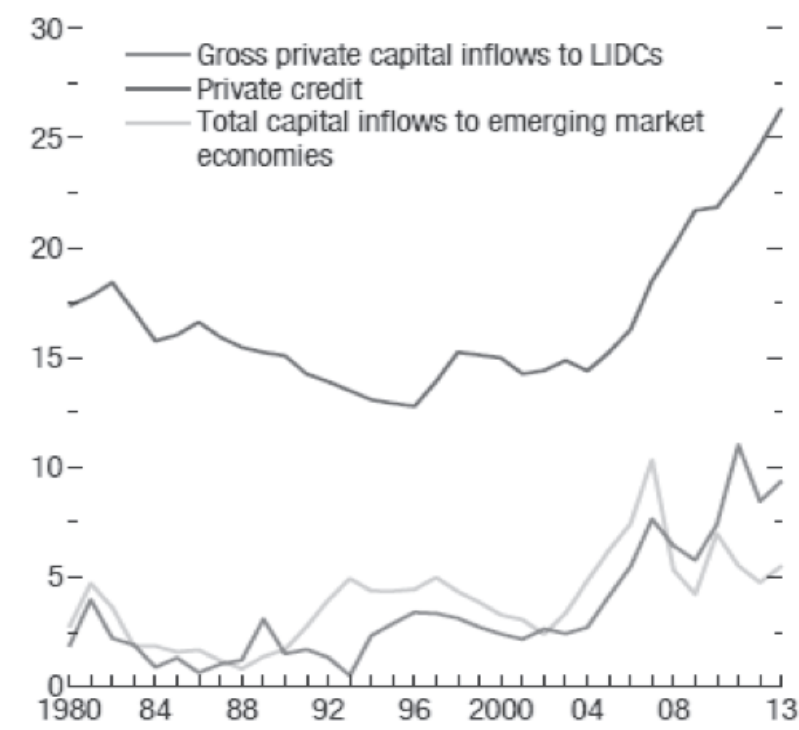

Source: IMF, October 2015 World Economic Outlook database

Note: Gross private capital inflows and private credit refers to 36 low-income developing countries and total gross capital inflows to emerging markets are based on IMF staff calculations

\subsection{Determinants of Capital Inflows - Empirical Evidence}

The determinants of capital flows have been broadly analysed in the literature related to the subject. The literature basically examines the determinants of capital flows from developed countries to developing and emerging market economies, in the context of push and pull factors. The low interest rate and volatility in the exchange rate in developed countries, lead to the inflow of capital to developing countries, with stable policies, improved creditworthiness and growing liberalised financial markets (Arshad et al, 2012). The relative role of push factors and pull factors vary across different empirical studies. Determining the relative role of push and pull factors in driving capital flows is a crucial issue regarding the actions of the policy makers in capital recipient countries. If capital flows are determined by push factors, domestic policymakers will have little space to control the capital flows. On the other hand, to the extent that capital flows are determined by pull factors, domestic policymakers will have more power on capital flows by introducing sound macroeconomic policies 
(Culha, 2006). Further, since different factors cause different types of capital flows, the examination of the disaggregate level would give more insights into formulating policies.

Several studies have examined determinants of capital flows using panel data. In most of the studies, real GDP, current account balance, budget balance, interest rates, labour laws and judiciary system have been used as pull factors. Moreover, many studies which focused on pull factors suggested that stable macroeconomic conditions determine capital flows. In the study carried out by Husain and Jun (1992) on two sub groups, South Asian and ASEAN, reveal that an ample supply of low wage, skilled and educated labour would attract FDI inflows when considering the comparative advantage of South Asian economies. Ralhan (2006) carries a cross-sectional study of eight countries to identify the determinants of capital flows, especially in the wake of economic liberalisation and deregulation, covering the period of 1970-1995. Based on the findings, he suggests that government policies should be directed towards improving the fundamentals of the economy, such as gross foreign reserves, gross domestic product and total external debts in order to attract capital inflows. He finds that gross foreign reserves are one of the most important factors affecting capital flows in all the countries considered, regardless of any region or group. The level of gross domestic product is another factor influencing capital flows and growth in the size of an economy can lead to an increase in capital flows because of growing investors' confidence. The findings of the study of Arshad et al (2012) using the annualised data of six developing Asian countries for the period of 1990-2009 indicate that the dependence on the capital inflow is significant on the reserves, GDP and fiscal policies of the country. Yang et al, (2013) examine the determinant of FDI and foreign portfolio investment using the static and dynamic models of six Asian countries and seven Latin American countries. Their results show that expectation factors are in great importance with the FDI and foreign portfolio investment in those two regions and that FDI is highly influenced by the economic expectation, while foreign portfolio investment is dependent upon exchange rate expectation.

In the meantime, several studies find that push factors play a major role in determining capital inflows. Kim (2000) investigates the causes of capital flows in four developing countries; Mexico, Chile, Korea and Malaysia, using structural decomposition analysis and finds that the resurgence in capital movements is largely due to external factors such as decreases in the world interest rate or recession in industrial countries, whereas domestic factors including country specific productivity shocks and demand shocks are relatively less important. Brana and Lahet (2008) investigate the impacts of both external factors and domestic fundamentals on the evolution of capital inflows with a panel of four Asian countries over the period of 1990-2007. Their findings show that both push and pull factors are significant. Push factors such as trade strategies, global 
liquidity and contagion factors seem to be major determinants of capital inflows into Asia. However, sovereign ratings, as pull factors, are not the major determinant of capital inflows in Asia during this period.

There are several studies carried out to examine the determinants of capital flows in the context of a single country. Culha (2006) analyses the determinants of capital inflows to Turkey by introducing a Structural Vector Autoregression (SVAR) model with producing impulse response and variance decomposition functions covering the period from 1992:01 to 2005:12. The same analysis has also been carried out for the two sub-periods 1992:01-2001:12 and 2002:01-2005:12 to inspect if there exists a change in the roles of push and pull factors before and after the 2001 economic crisis. The impulse-response analysis in the whole sample period reveals that shocks to foreign interest rates (US interest rate) tend to increase, whereas shocks to domestic real interest rates tend to decrease capital flows to Turkey, which is an inconsistent phenomenon. The analysis over the second sub-period 2002:01-2005:12 points to a 'normalisation' of the economy where the foreign interest rate shocks cause capital outflows and domestic interest rate shocks cause capital inflows, as expected. Impulse response analysis, in general, suggests that shocks to foreign industrial output and exchange index has a positive effect on capital flows into Turkey. There appears to be a negative relation between the shocks to both budget and current account balances and capital flows. Thus Culha concludes that pull factors are dominant over push factors in the determination of capital flows to Turkey during the whole sample period. Similarly, Asraf et al, (2010) in their study reveal that pull factors are imperative in explaining the capital flows into Malaysia. Therefore, budget balance and current account balance appear to be the most influential variables that affect inflows of capital into Malaysia.

There is a long-standing impression among policymakers that FDI is more conducive to long-run growth and development than other forms of capital inflows. Hence, several studies have been conducted to examine the determinants of FDI only, rather than capital inflows as a whole. Rehman et al, (...) empirically investigate the determinants that are responsible for the insufficient FDI inflow to Pakistan, through testing how important political stability and energy availability are in attracting FDI, beside other determinants during the period of $1980-2008$. They found that the political instability eroded the investors' confidence in the country and conclude that stability rather than democracy was more important in the choice of the investment decisions. 


\section{Capital Flows into Sri Lanka}

\subsection{Trends and Composition of Capital Flows into Sri Lanka}

Capital inflows began to play an important role in the Sri Lankan economy after the open economy in 1977. With the open economy, the external sector responded positively to the new incentives. Exports and imports of goods and services expanded, leading to an expanded deficit of the current account, while bilateral and multilateral donors provided large amounts of grants and concessional loans for development work. Meanwhile, foreign private capital inflows increased. Accordingly, the Sri Lankan economy became increasingly integrated with the world economy (CBSL, 1998). Prior to 1977, the trade account largely determined the current account balance. After 1977, private transfers, which largely represent worker remittances from abroad, increased and helped to off-set the impact of enlarged trade deficits on the level of foreign exchange reserves in the country. Meantime, concessional donor assistance was utilised to finance massive infrastructure development projects.

\section{(a) Foreign Direct Investment (FDI)}

FDI, which is the principal source of private capital inflows, amounted to US dollars 47 million in 1979 after the initial liberalisation of the economy in 1977. However, this initial momentum could not be maintained due to the loss of Sri Lanka's investment potential as a result of the escalation of ethnic problems into a civil war in 1983. As an example, two electronic manufacturing giants, namely Motorola and the Harris Corporation, which obtained approval from the Board of Investment of Sri Lanka (BOI) to establish plants inside the Katunayake free trade zone in 1982, withdrew their investment projects from Sri Lanka with the uncertainty created by the war (Kelegama 2006). However, with the implementation of the second wave of liberalisation and structural adjustments in 1989, the relative improvement of the macroeconomic environment and other reforms introduced by the government, including the privatisation of state owned enterprises (SOEs), FDI increased gradually (Pushparajah, 2009). As a result, more than two-thirds of the SOEs were acquired by foreign investors in the 1990s (CBSL, 2002).

Before the recovery from the set-back in the late 1990s, the adverse impact of the 9/11 attack in 2001, as well as the attack on Sri Lanka's international airport by the Liberation Tigers of Tamil Eelam (LTTE) caused a drop in FDI flows. However, with the signing of a peace agreement with the LTTE in 2002, a conducive economic environment was visible in the country. Although the LTTE withdrew from negotiations and the government decided to crush the rebels in 2005, FDI flows into the sector have shown a steady growth from 2003. In the year 2011, the country attracted significant inflows of FDI, consequent to achieving sustainable peace after the ending 
of humanitarian operations in May 2009. This increasing trend continued thereafter and FDI, excluding borrowings of direct investment enterprises (DIEs) reached US dollars 944 million in 2014, with the improved investor sentiment underpinned by a stable macroeconomic environment. Figure 2 shows the increase in FDI along with other capital inflows after end of the civil war.

\section{Figure 2: Inflows to the Financial Account}

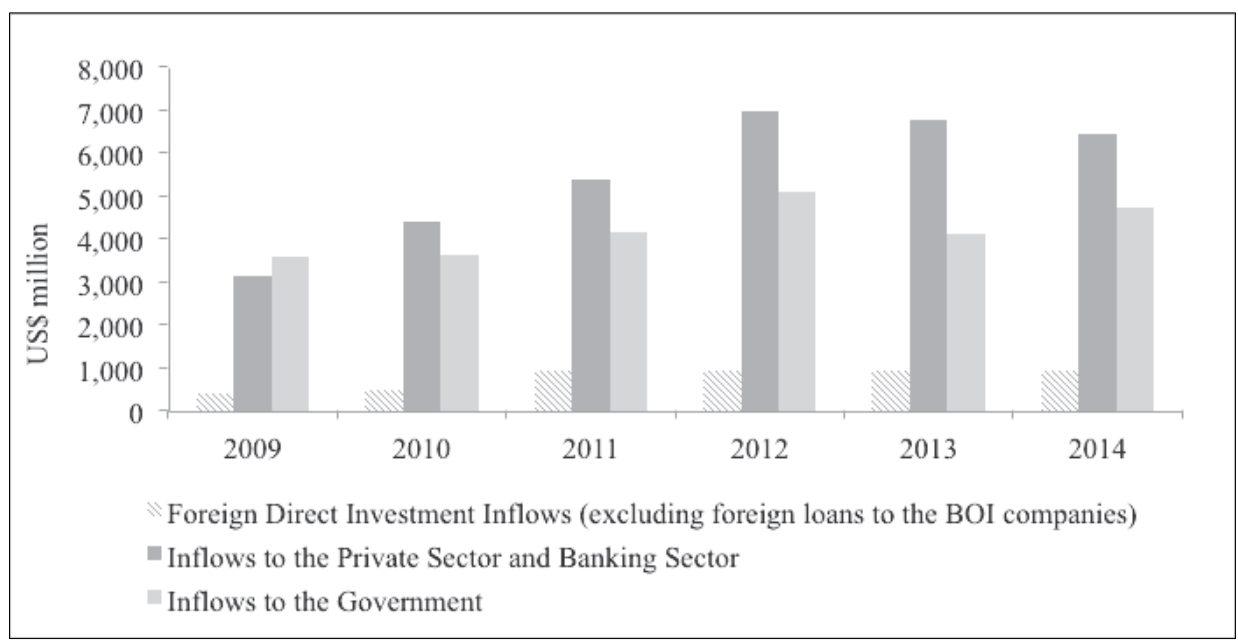

Source: Central Bank of Sri Lanka

\section{(b) Portfolio Investment}

Notwithstanding the continuing importance of FDI flows, the significance of portfolio flows has also increased in the recent past. Portfolio investment amounted to US dollars 31 million in 1991 with the approval granted for foreign investment in shares of companies incorporated in Sri Lanka. By 1994, private capital portfolio investments increased to US dollars 293 million (2.5\% of GDP). The recession and low interest rates in industrialised countries were the main external push factors, whereas high domestic interest rates, further capital account liberalisation and contemporary boom conditions in the Colombo Stock Exchange were some of the important pull factors for this development (Pushparajah, 2009). During 1998-2002, portfolio investments were low due to low profitability of corporate sector, political instability, loss of investor confidence and the heightened security situation. However, it increased again with the improved investor confidence after signing the ceasefire agreement with the LTTE in 2002. With the end of the civil war in 2009, portfolio investments increased considerably. In 2014, inflows in the form of equity and investment fund shares, which 
comprise foreign investments other than direct investments in Colombo Stock Exchange (CSE) listed companies, moderated (CBSL, 2014).

\section{(c) Other Investments}

Other investment inflows, consisting of private and public sectors' foreign borrowings and suppliers' credits to private sector importers, have been continuously increasing in the post-liberalisation era. The credit extended by foreign suppliers has been growing with the higher import expenditure. The demand for foreign borrowing by the private sector, including public corporations, increased during the 1990s, as there was increased access to foreign funds at relatively low rates of interest rather than the domestic interest rates (Pushparajah, 2009). However, since Sri Lanka graduated to a lower middle income country, the level of capital grants, which is a large part of inflows to the capital account, has declined in the recent past.

\subsection{Macroeconomic Indicators as Drivers of Capital Flows}

As high and sustainable economic growth is an indicator of higher long term prospects for investment, it is one of the key drivers of capital inflows. The Sri Lankan economy recorded a 4.2 per cent growth in 1977 and grew by over 5 percent thereafter till 1985 . Economic growth has been strong in recent past, specially after the end of the war. The real GDP grew by around 5.7 per cent on average during 2002-2009, after recording a negative growth rate of 1.5 per cent in 2001, the first time since independence. An unfavourable global economic environment, that adversely affected the performance of manufacturing and external trade, the prolonged drought that affected the agricultural output and hydropower generation, coupled with the terrorist attack on the international airport at Katunayake, the subsequent imposition of insurance surcharges on sea and air travel and political uncertainties contributed to this negative growth. Meanwhile, the economy recorded its highest ever growth of 9.1 per cent in 2012. In 2014, the Sri Lankan economy grew by 4.5 per cent.

Inflation, measured based on the Colombo Consumer Price Index (CCPI) increased after the economic liberalisation not only due to the immediate direct effect of the relaxation of price controls, currency devaluation and the removal of subsidies, but also due to continued high budget deficits, which were financed through expansionary sources (CBSL, 1998). Inflation increased to 12.1 per cent in 1978, from 1.2 per cent in 1977 and recorded 26.1 per cent in 1980, the highest level since independence. A fiscal consolidation programme that was initiated since 1995 with the objective of moving the economy to a non-inflationary high growth path caused the containment of inflation at a single digit level by end 1997 . The inflation rate increased to a double digit figure in 
2001 due to the temporary supply shortage of domestically produced major food items caused by the drought, upward adjustments in administered prices, higher import prices etc. With the prudential policy measures and favourable conditions in the international commodity market, Sri Lanka was able to maintain inflation at a single digit level during the last six years since February 2009 and the annual average headline inflation stood at 3.3 per cent by end December 2014.

\section{Figure 3: Real GDP Growth and Inflation}

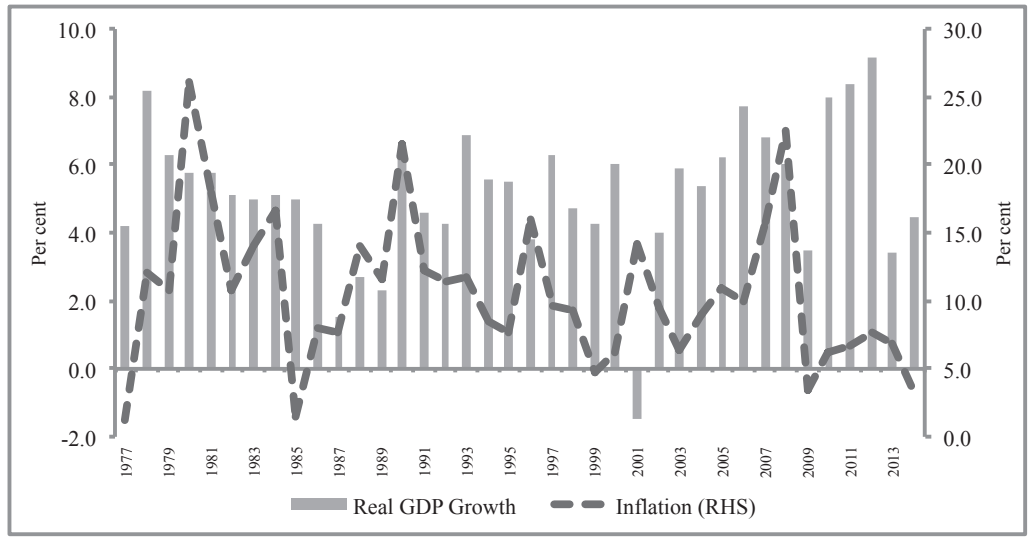

Source: Central Bank of Sri Lanka

The post-independence governments have played a key role in the upliftment of the socio-economic status of the people in Sri Lanka. Despite the economic liberalisation in 1977, the share of the public sector in the economy remained high. Accordingly, Sri Lanka has experienced a high budget deficit for a long period of time and it peaked at 19.2 per cent of GDP in 1980. With the economic reforms in 1977, government involvement in heavy capital expenditure projects, such as the Accelerated Mahaweli Development Programme, power generation and ports development projects had an impact on the increase of capital expenditure, leading to an expansion in the budget deficit. After the completion of these projects, the budget deficit declined to around 7.9 per cent of GDP during the 1990s (CBSL, 1998). The budget deficit narrowed down from 2002, except in the year 2009, reflecting a favourable trend towards the fiscal consolidation and amounted to 6.0 per cent of GDP in 2014.

The current account balance, which represents the external sector fragility, recorded a deficit after the economic reforms in 1977. During the 1978-1985 period, the current account deficit widened to 8.2 per cent of GDP, reflecting the increase of imports due 
to the high demand with expanding economic activity, funded large infrastructure development projects and export processing zones (Perera and Liyanage, 2011). However, with the expansion of exports and improvement in both services and transfers accounts, as well as the completion of large donor funded development projects, the current account deficit declined significantly from the high levels of the 1980s and has remained at a single digit level since then. In 2014, the current account deficit declined to 2.7 per cent of GDP with the surplus in the services account and increase in workers' remittances (CBSL, 2014).

The 91 T-bill rate, which is used as the proxy to domestic interest rate in compiling the interest rate differential was 9 per cent in 1977 and was also relatively low volatility particularly during the period of 1989-1996. However, in 1997, the 91 T-bill rate dropped drastically to 9.97 per cent from 17.45 per cent in 1996 and continued to remain low during 2002-2004 and 2009-2014. The same trend has been observed in the 6 month and 1 year T-bill rate.

Table 1: Key Macroeconomic Performance in Sri Lanka (1960 - 2014)

\begin{tabular}{|c|c|c|c|c|c|c|}
\hline \multicolumn{7}{|c|}{ Averages for Decades } \\
\hline Indicator & $\begin{array}{l}1960- \\
1969\end{array}$ & $\begin{array}{l}1970- \\
1979\end{array}$ & $\begin{array}{l}1980- \\
1989\end{array}$ & $\begin{array}{c}1990- \\
1999\end{array}$ & $\begin{array}{l}2000- \\
2009\end{array}$ & $\begin{array}{l}2010- \\
2014\end{array}$ \\
\hline GDP (US dollars million) & 1,658 & 3,125 & 5,745 & 12,230 & 25,623 & 67,283 \\
\hline Real GDP Growth (\%) & 4.7 & 3.9 & 4.3 & 5.2 & 5.0 & 6.7 \\
\hline Budget Balance ( $\%$ of GDP) & -6.0 & -7.1 & -11.3 & -7.9 & -8.1 & -6.7 \\
\hline $\begin{array}{l}\text { Current Account Balance } \\
(\% \text { of GDP) }\end{array}$ & -2.8 & -2.0 & -7.7 & -4.8 & -3.5 & -4.7 \\
\hline Interest Rate - 91 days & & & & & & \\
\hline Treasury bill rate $(\%)$ & 3.1 & 6.2 & 13.6 & 15.9 & 12.4 & 7.8 \\
\hline Exchange Rate (US & & & & & & \\
\hline dollar/Rupee) & 5.0 & 8.6 & 25.8 & 52.3 & 99.7 & 122.2 \\
\hline Inflation (\%) & 2.2 & 6.9 & 12.8 & 11.3 & 10.8 & 6.1 \\
\hline
\end{tabular}

Sources: Perera and Liyanage (2011)

Central Bank of Sri Lanka

\subsection{Government Policies for Capital Flows}

With the restrictive and inward oriented policies i.e., the reemergence of a comprehensive system of quantitative restrictions, high tariffs and foreign exchange 
controls that were implemented from 1970 to 1977, private capital inflows were at negligible levels. However, with the first phase of Sri Lanka's economic liberalisation under the open economic regime introduced in 1977, capital inflows as a percent of GDP rose to 6 per cent in 1978 from a level of under 1 per cent in the previous year and private capital, both direct investment and loans, turned from a net outflow to a net inflow. With the establishment of the Greater Colombo Economic Commission (later Board of Investment) in 1978 and the first Export Processing Zone, direct inflows grew significantly (CBSL, 1998).

The second phase of economic liberalisation commenced in the early 1990s with the initiation of a mass-scale privatisation programme and the liberalisation of the stock market investments. Subsequently, trade and payment systems were also liberalised and concerted efforts to increase private capital inflows were introduced in 1991. With the approval for foreign nationals to purchase 100 per cent of the issued share capital in the listed companies in 1992, subject to certain exclusions and limitations, Sri Lanka experienced a surge in portfolio investment during 1993 - 1994. Meantime, with the full liberalisation of current transactions in 1993, Sri Lanka accepted obligations under Article VIII of the IMF in 1994, while gradually relaxing the capital account transactions (Amarasekara, 2004). In 1995, commercial banks were permitted to obtain foreign loans up to 15 per cent of their capital and reserves. Further, Sri Lanka abandoned its managed floating exchange rate regime and adopted a full float in 2001 and non-residents were permitted to invest in dollar denominated government securities. Similarly, the country witnessed a surge in capital flows in 2007 and 2008, with the issuance of sovereign bonds in the international markets, higher FDI inflows and increased foreign investment in the Colombo stock market. In 2010, foreign companies were permitted to open places of business in Sri Lanka, while non-residents were permitted to invest in rupee denominated debentures issued by local companies (CBSL, 2010). In 2011, the threshold for foreign investments in Treasury bills and Treasury bonds was increased to 12.5 per cent from 10 per cent of the outstanding Treasury bills and Treasury bond stock, respectively. In 2013, general permission was granted to foreign institutional investors, corporate bodies incorporated outside Sri Lanka and investors resident outside Sri Lanka, to invest in Unit Trusts, subject to certain conditions. Overall, Sri Lanka has taken several progressive measures in order to promote financial openness and enhance a positive investment climate, moving beyond more conventional measures such as offering costly tax concessions, supplying of unskilled labour at low cost etc. Policy focus has shifted towards implementing a proper investment promotion strategy, underpinned by various factors such as political and social stability, improved infrastructure, skilled labour and efficient government institutions (CBSL, 2010). 
However, Sri Lanka having realised the potential disrupting effects of free capital movement, has sought to promote long-term capital inflows rather than short-term flows. Therefore, certain portfolio investment areas in Sri Lanka still remain closed to foreign participation.

\section{Methodology}

\subsection{Model Specification}

The determinants of capital flows into Sri Lanka are examined using two different approaches; single equation Fully Modified Ordinary Least Squares (FMOLS) Regression and Vector Error Correction Model (VECM).

The FMOLS approach, proposed by Philip and Hansen (1990), provides optimal estimates of Co-integration regression. The basic idea of the FMOLS approach is to account for the serial correlation and test for the endogenity in the regressors that result from the existence of a co-integrating relationship. Based on the theoretical and empirical concepts, which discussed above, the model for determinants of capital flows is arranged as follows.

$$
\mathrm{LNCF}=\beta_{0}+\beta_{1} \mathrm{LNRGDP}+\beta_{2} \mathrm{BB}+\beta_{3} \mathrm{CAB}+\beta_{4} \mathrm{IR}+\beta_{5} \mathrm{PSC}+\beta_{6} \mathrm{INIPI}+\beta_{7} \mathrm{D} 1+\varepsilon_{\mathrm{t}}
$$

Variables and their expected signs are presented in Table 2.

Table 2: Definition of Variables

\begin{tabular}{|c|c|c|}
\hline & Definition & Expected sign \\
\hline \multirow{2}{*}{$\begin{array}{l}\text { Push Factors } \\
\text { AIPI }\end{array}$} & & \\
\hline & $\begin{array}{l}\text { World GDP (proxied by industrial production index of } \\
\text { advanced economies } 2010=100 \text { ) }\end{array}$ & $+/-$ \\
\hline \multicolumn{3}{|c|}{ 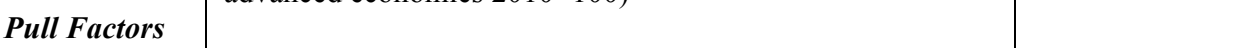 } \\
\hline LNRGDP & Log of Real Gross Domestic Products & + \\
\hline $\mathrm{BB}$ & $\begin{array}{l}\text { Budget balance (deficit) defined as the difference between } \\
\text { government revenue and government expenditure }\end{array}$ & $+/-$ \\
\hline $\mathrm{CAB}$ & $\begin{array}{l}\text { Current account balance (deficit) is defined as net exports of } \\
\text { goods and services plus net factor income }\end{array}$ & $+/-$ \\
\hline IR & $\begin{array}{l}\text { Interest rate deferential defined as the difference between } \\
\text { annualised Sri Lankan month Treasury bill rate and } 3 \text { month } \\
\text { LIBOR rate }\end{array}$ & + \\
\hline PSC & $\begin{array}{l}\text { Year-on-year growth of credit granted by licensed banks to } \\
\text { private sector }\end{array}$ & + \\
\hline D1 & $\begin{array}{l}\text { Dummy variable to capture the civil war prevailed in Sri } \\
\text { Lanka }\end{array}$ & - \\
\hline
\end{tabular}


It is observed that the RGDP has a positive relation with $\mathrm{CF}$, as an economically thriving country can attract more inflows of capital. In contrast, the $\mathrm{BB}$ and $\mathrm{CAB}$ are anticipated to have either positive or negative relationships with CF depending on how the variables are perceived. If the variables are looked at, as fiscal and external fragilities to a country, respectively, these two variables might have a negative relationship with capital inflows. This is because large budget and current account deficits denote unfavorable domestic economic conditions, thus making a country less attractive to capital inflows from abroad. However, if we consider the variables from a direct angle, they might have a positive nexus with capital inflows, as widening deficits in current account and budget balances imply a substantial demand for capital inflows from other countries to finance the deficits (Abdullah, 2010). The IR is expected to have a positive relationship since higher domestic interest rate attracts foreign capital. The PSC is expected to have a positive relationship with CF since the development of the financial sector, represented by PSC, would attract more capital flows. The strength of the advanced countries' economy, which is proxied by AIPI, may have two implications on capital flows into emerging/developing economies. On one hand, an improvement in the industrial production index shows the ability of advanced countries in accumulating capital to fund economic activities in developing countries. On the other hand, it leads to inflationary pressure in advanced economies, hence raises its interest rates. Higher interest rates in advanced economies attract inflows of capital into advanced countries, thereby reducing the amount of capital flows to emerging/developing economies (Puah, 2010). D1 is expected to have a negative relationship since political instability causes less attraction in capital inflows.

This study consists of 4 specifications. Specification 1, the main model, employs total capital flows as a dependent variable. The dependent variable in specification 2, 3 and 4 is FDI, portfolio investment and other capital inflows, respectively.

\subsection{Data Description}

This study uses quarterly data which span from 2001Q1 to 2015Q2. Data are obtained from various issues of Annual Reports of the Central Bank of Sri Lanka (CBSL) and the International Financial Statistics (IFS) published by the International Monetary Fund (IMF). The reason for employing data from 2001 is that it was the year that Sri Lanka liberalised the foreign exchange market by allowing the commercial banks to determine the exchange rate. Inflows data for the year 2012Q1 to 2015Q2 have been compiled based on the Balance of Payments Manual 6 (BPM6), while data for the balanced period have been compiled based on the BPM5.

The dependent variable in this study is the capital inflows (CF), which is obtained by summing up FDI, portfolio investment, government long-term loans and private sector 
long-term loans. The rational to form aggregated data from these four flows is that they are major components of capital flows in the financial account of a country. The independent variables used in this study include both the pull and push factors that affect capital flows into a country. For the pull factors, RGDP is applied because it neutralises the effect of inflation and represents the domestic performance of an economy and is widely cited in many literatures on the determinant of capital inflows into a country (Abdullah et al, 2010). BB, which is obtained by deducting total government expenditure from total government revenue, denotes the fiscal fragility of a country. The $\mathrm{CAB}$ indicates the external sector fragility. IR refers to the interest rate differential, which is the difference between the annualised Sri Lankan 91-Tbill rate and 3 month US LIBOR. The PSC represents the financial development of the country. Further, global financial crisis during 2007-2009 and internal conflict until 2009 were included the sample period. The effect of the internal conflict of the country on capital inflows is captured in dummy variable $1(\mathrm{D} 1)^{3}$. The push factor examined in this study is the industrial production index of advanced economies (AIPI), which is used as the proxy for advanced countries' economic performance. Variables CF and RGDP are in natural logarithm form and all variables are seasonally adjusted to remove seasonal effects.

\subsubsection{Descriptive Statistics}

The descriptive statistics of the final data series used in the analysis after required transformations for the full sample are given in Table 3.

Table 3: Descriptive Statistics with Transformed Data

\begin{tabular}{|lccccccc|}
\hline & LNCF & LNRGDP & \multicolumn{1}{c}{ BB } & \multicolumn{1}{c}{ CAB } & IR & PSC & AIPI \\
\hline Mean & 6.28 & 7.09 & -724.29 & -408.24 & 2.37 & 15.90 & 102.02 \\
Median & 6.31 & 6.84 & -603.53 & -309.84 & 2.13 & 15.17 & 101.86 \\
Maximum & 7.72 & 9.22 & -229.31 & 148.82 & 4.42 & 35.13 & 111.29 \\
Minimum & 4.79 & 5.45 & $-1,777.74$ & $-1,547.84$ & 1.11 & -5.92 & 90.71 \\
Std. Dev. & 0.68 & 0.97 & 393.11 & 435.59 & 0.86 & 10.38 & 4.63 \\
Observations & 58 & 58 & 58 & 58 & 58 & 58 & 58 \\
\hline
\end{tabular}

Table 3 shows that, on average, the budget deficit amounted to US dollars 724 million per quarter, while the current account deficit amounted to US dollars 408 million.

3 Since AIPI reflects the impact of global financial crises on advanced economies, it is not included as an explanatory variable. 
The interest rate differential has been, on average, around 2.4 per cent. The credit granted to the private sector by licensed banks has increased on average, by 15.9 per cent, year-on-year, while the AIPI was around 102.0 index points. All variables show considerable volatility.

\subsubsection{Stationarity Properties of Data}

In this study, the Augmented Dickey-Fuller (ADF) unit root test and Phillips-Perron (PP) test are utilised to examine the stationarity properties of the data used in the model. The optimal lag length is selected based on Schwarz Information Criterion (SIC). These unit root tests are performed on both level and first differences. Summary results of the ADF test and PP test are given in Table 4.

Table 4: Results of Unit Root Tests

\begin{tabular}{|l|l|c|c|c|c|}
\hline \multirow{2}{*}{ Variable } & \multirow{2}{*}{ Indicator } & \multicolumn{2}{|c|}{ ADF Test } & \multicolumn{2}{c|}{ PP Test } \\
\cline { 3 - 6 } & & Level & 1st difference & Level & 1st difference \\
\hline \multirow{2}{*}{ LNCF } & t-Statistic & 1.1940 & -11.7620 & 0.6705 & -12.3871 \\
\cline { 2 - 6 } & P-Value & 0.9386 & 0.0000 & 0.8579 & 0.0000 \\
\hline \multirow{2}{*}{ BB } & t-Statistic & 0.6197 & -9.3515 & 1.1655 & -9.5215 \\
\cline { 2 - 6 } & P-Value & 0.8474 & 0.0000 & 0.9355 & 0.0000 \\
\hline \multirow{2}{*}{ CAB } & t-Statistic & 1.6254 & -10.7001 & -1.4091 & -27.6904 \\
\cline { 2 - 6 } & P-Value & 0.9733 & 0.0000 & 0.1462 & 0.0000 \\
\hline \multirow{2}{*}{ IR } & t-Statistic & -1.5375 & -4.7787 & -1.4818 & -3.5878 \\
\cline { 2 - 6 } & P-Value & 0.1155 & 0.0000 & 0.1282 & 0.0006 \\
\hline \multirow{2}{*}{ PSC } & t-Statistic & -2.4450 & -4.7014 & -0.8478 & -4.7442 \\
\cline { 2 - 6 } & P-Value & 0.1345 & 0.0003 & 0.3443 & 0.0000 \\
\hline \multirow{2}{*}{ AIPI } & t-Statistic & -0.3139 & -4.8868 & -1.2055 & -3.2957 \\
\cline { 2 - 6 } & P-Value & 0.5674 & 0.0000 & 0.2063 & 0.0014 \\
\hline \multirow{2}{*}{ LNFDI } & t-Statistic & 0.2086 & -3.9409 & 0.1290 & -3.8973 \\
\cline { 2 - 6 } & P-Value & 0.7432 & 0.0002 & 0.7194 & 0.0002 \\
\cline { 2 - 6 } & t-Statistic & 0.9389 & -8.3652 & 1.0527 & -8.3529 \\
\hline \multirow{2}{*}{ LNPFI } & P-Value & 0.9055 & 0.0000 & 0.9217 & 0.0000 \\
\cline { 2 - 6 } & t-Statistic & 0.2913 & 0.7667 & 0.4288 & -11.3526 \\
\cline { 2 - 6 } & P-Value & 0.7667 & 0.0000 & 0.8031 & 0.0000 \\
\cline { 2 - 6 } & t-Statistic & 0.6422 & -8.6864 & 0.1779 & -12.1240 \\
\cline { 2 - 6 } & P-Value & 0.8520 & 0.0000 & 0.7342 & 0.0000 \\
\hline \multirow{2}{*}{ LNOCF } & & & -129 & $C$ \\
\hline
\end{tabular}

Source: Author's Calculations 
At levels, all the variables failed to reject the null hypothesis of 'the series has a unit root' at a 5\% significant level. Accordingly, all the variables are non-stationary at levels and stationary after the first differencing, hence they are said to be I(1) variables.

\section{Empirical Results}

Following the unit root test results shown in Table 4, which indicate that the time series variables are integrated of order one I(1), the next step is to examine whether or not there is at least one linear combination of the variables that is integrated of order zero, $\mathrm{I}(0)$, and hence, if there exists a stable and non-spurious cointegrated relationship in the long run between time series variables (Miguel, 2000). Accordingly, the co-integration test is performed.

\subsection{Co-integration Test Results}

The Johansen approach can determine the number of cointegrated vectors for any given number of non-stationary variables of the same order. The results of trace statistics and Johansen's maximum likelihood test, based on maximum eigenvalue of stochastic matrix are shown in Table 5.

\section{Table 5: Co-integration Test Based on Trace Statistic}

\begin{tabular}{lcc}
\hline Specification & $\begin{array}{c}\text { Trace Test } \\
\mathrm{r}=0\end{array}$ & $\begin{array}{c}\text { Maximum Eigen } \\
\text { Value Test }\end{array}$ \\
\hline Specification 1 & $153.40^{* * *}$ & $50.21^{* * *}$ \\
Specification 2 & $158.84^{* * *}$ & $50.05^{* * *}$ \\
Specification 3 & $162.52^{* * *}$ & $56.03^{* * *}$ \\
Specification 4 & $153.98^{* * *}$ & $49.06^{* * *}$ \\
\hline
\end{tabular}

Note: Specification 1, 2, 3 and 4 represent total capital inflows, FDI, portfolio investment and other capital inflows, respectively, as the dependent variable.

Co-integration test confirms the existence of a long-run equilibrium relationship between the variables. 


\subsection{Long-run FMOLS Results}

Since the model variables are co-integrated, the long-run FMOLS estimate developed by Philip and Hansen (1990) can be used to identify and estimate the impact of variables that exert influence on capital inflows. The FMOLS technique has an edge over the Ordinary Least Square (OLS) technique that it is able to take into account both the serial correlation and endogeneity problems present in the variables.

\section{Table 6: Results of Fully Modified Ordinary Least Squares Regression}

\begin{tabular}{|c|c|c|c|c|}
\hline \multirow[b]{2}{*}{$\begin{array}{c}\text { Independent } \\
\text { Variable }\end{array}$} & \multicolumn{4}{|c|}{ Dependent Variable } \\
\hline & $\begin{array}{c}\text { Total } \\
\text { Capital } \\
\text { Inflows }\end{array}$ & $\begin{array}{c}\text { Foreign } \\
\text { Direct } \\
\text { Investment }\end{array}$ & $\begin{array}{c}\text { Portfolio } \\
\text { Investment }\end{array}$ & $\begin{array}{c}\text { Other } \\
\text { Investment }\end{array}$ \\
\hline \multirow{2}{*}{ Log Real GDP } & 0.1584 & 0.3799 & 0.3581 & 0.0760 \\
\hline & {$[1.9840]^{*}$} & {$[5.3557]^{* * *}$} & {$[2.0098]^{* * *}$} & {$[0.8419]$} \\
\hline \multirow{2}{*}{ Budget Balance } & -0.0005 & -0.0002 & -0.0006 & -0.0005 \\
\hline & {$[-3.2184]^{* * *}$} & {$[-1.7433]^{*}$} & {$[-1.8664]^{*}$} & {$[-2.9222]^{* * *}$} \\
\hline \multirow{2}{*}{$\begin{array}{l}\text { Current Account } \\
\text { Balance }\end{array}$} & -0.0001 & -0.0003 & -0.0001 & $-4.94 \mathrm{E}-05$ \\
\hline & {$[0.9094]$} & {$[-2.3314]^{* *}$} & {$[-0.3416]$} & {$[-0.3074]$} \\
\hline \multirow{2}{*}{$\begin{array}{l}\text { Interest Rate } \\
\text { Differential }\end{array}$} & 0.1327 & 0.1844 & 0.0445 & 1.1461 \\
\hline & {$[2.3042]^{* *}$} & {$[3.6031]^{* * *}$} & {$[0.3464]$} & {$[2.2431]^{* *}$} \\
\hline \multirow{2}{*}{$\begin{array}{l}\text { Private Sector Credit } \\
\text { Growth }\end{array}$} & 0.0076 & 0.0091 & -0.0056 & 0.0127 \\
\hline & {$[1.4104]$} & {$[1.9096]^{* * *}$} & {$[-0.4639]$} & {$[2.0912]^{* *}$} \\
\hline \multirow{2}{*}{$\begin{array}{l}\text { Industrial Production } \\
\text { Index of Advanced } \\
\text { Economies }\end{array}$} & 0.0399 & 0.0618 & 0.1092 & 0.0136 \\
\hline & {$[3.8679]^{* * *}$} & {$[6.7299]^{* * *}$} & {$[4.7369]^{* * *}$} & {$[1.1564]$} \\
\hline \multirow{2}{*}{$\begin{array}{l}\text { Dummy Variable for } \\
\text { Civil War }\end{array}$} & -0.4566 & -0.0821 & -0.2945 & -0.5927 \\
\hline & {$[-2.8932]^{* * *}$} & {$[-6.2851]^{* *}$} & {$[-4.8360]^{* *}$} & {$[-3.3193]^{* * *}$} \\
\hline \multirow{2}{*}{ Constant } & 0.5177 & -5.142 & -9.798 & 3.3203 \\
\hline & {$[0.4467]$} & {$[-4.9934]^{* * *}$} & {$[-3.7879]^{* * *}$} & {$[2.5325]^{* *}$} \\
\hline No. of Observations & 58 & 58 & 58 & 58 \\
\hline R-squared & 0.7802 & 0.8017 & 0.5882 & 0.6837 \\
\hline
\end{tabular}

t-statistics are in square brackets

* Significant at $10 \% \quad * *$ Significant at $5 \% \quad * * *$ Significant at $1 \%$

According to the FMOLS results, unlike push factors, pull factors have a different impact on different types of capital flows. For instance, Table 6 shows that some of these factors exhibit a high degree of association with FDI, whereas portfolio investment and other investment flows are weakly correlated with them. The GDP has a positive and significant impact on attracting all type of capital inflows. The results 
suggest that a 1 per cent increase in the GDP will increase the total capital inflows by 0.16 per cent. The 0.38 per cent of coefficient of real GDP, in relation to FDI, reflects that the real GDP is a main factor that attracts FDI. This result emphasises the important role that economic growth plays in attracting capital flows into Sri Lanka. $\mathrm{BB}$ has a negative relationship with capital inflows as expected and is significant. This relationship can be found with all different types of inflows including total inflows. The CAB is insignificant with all categories except FDI. The IR has a positive relationship with CFs and significant with total capital flows, FDI and other investment. Growth of credit to the private sector is significant only with FDI and other investment. As shown by the findings, the civil war has a negative impact on capital inflows, both in aggregate level and disaggregate levels. This clearly shows that political stability is very important to attract capital flows. In terms of push factors, the world industrial production index is positively associated with all types of capital inflows and is statistically significant at $1 \%$ level, except other investments.

The model is estimated under two alternative scenarios, i.e., model 1 and model 2 to check the robustness of the results. The results of alternative models are given in Appendix II. As an alternative to real GDP, industrial production index was used in the model 1 and government revenue was used for budget balance in the model 2 . Accordingly, is it found that economic performance and fiscal fragility of the country have a positive impact on capital inflows. Moreover, interest rate differential and industrial production index in advanced countries have a positive relationship with capital inflows in both alternative scenarios, whereas internal conflict has a negative relation.

\subsection{Vector Error Correction Model}

Next, considering the possible endogeneity among selected variables, this paper also uses the Vector Error Correction Model (VECM) to identify determinants of capital inflows. Table 7 shows the results of the VECM.

Table 7: Normalised Co-integrating Coefficients

\begin{tabular}{lccccccc}
\hline & \multicolumn{9}{c}{ Pull Factors } & & Push \\
& LNCF & LNRGDP & BB & CAB & IR & PSC & AIPI \\
\hline$\beta$ Coefficient & 1 & -1.311 & 0.005 & -0.004 & -1.459 & -0.178 & -0.004 \\
\hline Standard & 0.187 & 0.001 & 0.000 & 0.147 & 0.012 & 0.021 \\
\hline $\mathbf{T}$-Statistics & $-6.999^{* *}$ & $6.753^{* *}$ & $-11.826^{* *}$ & $-9.954^{* *}$ & $-14.417^{* *}$ & -0.166 \\
\hline
\end{tabular}

**Significant at $5 \%$ level 
Accordingly, the t-statistics confirm that LNRGDP, BB, CAB, IR and PSC are significant at a 5\% level. As per the results, the expected signs of all variables hold true. The coefficient of Error Correction Term of D(LNCF) is -0.328 . This indicates that 32.8 per cent of the deviation from the equilibrium is corrected within a quarter, taking around 3 quarters to reach long run equilibrium.

Accordingly, the determinants of capital flows into Sri Lanka can be specified as follows:

$$
\begin{aligned}
L N C F= & -13.05+1.31 \text { LNRGDP }-0.005 B B+0.004 C A B+1.46 I R+0.18 P S C+ \\
& 0.004 \text { INIPI }-2.36 \text { DI }
\end{aligned}
$$

As per the estimated equation above, a 1 per cent increase in the real GDP would increase the capital flows into Sri Lanka by 1.31 per cent, while an increase in budget deficit by 1 per cent, would decrease the capital inflows by 0.005 units. Capital inflows increase by 0.004 units when current account increases by 1 per cent, while a 1 per cent increase in the interest rate differential will lead to increase capital inflows by 1.46 per cent and 1 per cent increase in credit granted to the private sector will lead to increase capital inflows by 0.18 . Moreover, the internal conflict had a negative effect of 2.36 per cent on capital flows in to Sri Lanka.

\section{Discussions of Findings}

Findings of the study using FMOLS confirm that the variables, real GDP, interest rate differential and world GDP have a positive effect on the total capital inflows, while the budget deficit has a negative effect as expected. However, the current account balance and private sector credit growth are not significant. The results of the VECM confirm that real GDP, current account deficit, interest rate differential, private sector credit growth and world GDP have positive effects on the total capital inflows, while the budget deficit has a negative effect. All the variables, other than world GDP are significant.

Based on both techniques, an increase in the GDP is found to attract more capital flows to Sri Lanka in the long run. This is consistent with the findings of Ralhan (2006), Pushparajah (2009) and Puah et al (2010). Economic growth can lead to an increase in capital flows because of growing investors' confidence. Further, according to Fernandez-Arias and Montiel (1996), the growth in resources increases country creditworthiness, and the increase in creditworthiness attracts more capital flows. According to the results of FMOLS and VECM, the budget deficit has a negative sign as expected. This is consistent with the studies of Hernandez and Rudolf (1994), Dasgupta and Ratha (2000), Hernandrz et al. (2001), Kara (2007) and Abdulla et al. 
(2010), who suggest that the budget balance is imperative in explaining capital inflows. Based on the VECM, the current account deficit has a positive relationship with capital inflows. This result is not consistent with Culha (2006) who finds that the current account deficit and capital inflows have a negative relation, suggesting that the current account balance is perceived as an external fragility indicator. However, the widening current account deficit requires essentially foreign financing in terms of portfolio investments and/or foreign direct investments, leading to a rise in capital inflows. Further, the FMOLS results show that the current account balance is significant with the FDI. Based on FMOLS and VECM, IR, the interest rate differential, which is the proxy of the real return to capital exporting countries, has a positive relationship with capital inflows since higher returns encourage higher inflows. This is consistent with the findings of Celasun et al. (1999), which show that the short-run interest rate differential appears to be the most important pull factor in determining capital inflows to Turkey.

In terms of push factors, based on FMOLS results, the AIPI has a positive effect on capital inflows, in accordance with previous empirical evidence. For instance, Kim's (2000) study on four developing countries; Mexico, Chile, Korea and Malaysia finds that resurgence in capital movements is largely due to push factors such as recession in industrial countries or a decrease in the world interest rate.

Based on the FMOLS, when considering the capital inflows in disaggregates levels, the interest rate differential has a positive relationship only with FDI and other investments. With the increase in the interest rate differential, the domestic cost of financing increases for Direct Investment Enterprises, therefore, investors look more to equity financing other than debt financing, creating more attractive prospects for FDI to a country. The interesting point is that the $\mathrm{CAB}$ is significant only with FDI. Basically the rules and regulations pertaining to entry and operations of foreign investors, trade policy, privatisation policy and business facilitation measures are the main requirements to attract investment in the form of FDI. The BOI provides attractive incentives to foreign investors such as long tax holidays, tax exemption and duty free imports of investment goods as well as infrastructure development facilities, which were not captured in this model, nevertheless may also be important in attracting FDI.

The determinants of PFI are somewhat more complex because portfolio investment earnings are more likely to be tied to the broader macroeconomic indicators of a country. Like other factors, real GDP and AIPI have positive relations with PFI and are significant at a $1 \%$ level. This is consistent with the finding of Chukwuemeka (2008), which shows that PFI flows into Nigeria has a positive long run relationship with the growth of real non-oil GDP. However, other capital inflows i.e. government and private 
sector long term loans are significant only with the budget deficit, interest rate differential, credit to private sector and civil war.

\section{Conclusion and Policy Recommendations}

As in many developing countries, foreign capital flows are found to be one of the key sources of funds for Sri Lanka and are important to sustain economic development. Understanding the determinants of capital inflows is a key concern, because it may have a crucial impact on developing countries like Sri Lanka and its policy implications.

This study investigates the determinants of capital flows to Sri Lanka in 2001:1-2015:2, using the FMOLS approach and the VECM. As pull factors, real GDP, budget balance, current account balance, interest rate differential, credit to private sector and a dummy variable to capture the impact of the internal conflict prevailed in Sri Lanka, have been investigated, while industrial production index of advanced economies is used as a push factor. Further, since different factors cause different types of capital flows, the disaggregate level of capital inflows were examined to give more insights into formulating policies.

According to empirical findings, the FMOLS confirms that total capital flows into Sri Lanka are determined by real GDP, budget balance, interest rate differential, civil war and world GDP. Current account balance and credit to private sector are insignificant, in contrast to the many empirical evidences. However, in the disaggregate level, the current account deficit is positively correlated with FDI and credit to the private sector positively correlated with FDI and other investment. Based on the VECM, all considered variables, except budget deficit, have a positive effect on the total capital inflows as predicted. However, the coefficient of the industrial production index of advanced countries is not significant.

The findings suggest that pull factors have a dominant role in determining capital flows into Sri Lanka. The policy makers of a country cannot control the capital inflow in the form of FDI directly, but on the other hand they can control the macroeconomy that directly affects the inflows. Therefore, as a small open economy, it is vital for Sri Lanka to keep the domestic macroeconomic variables in the right order to attract more foreign capital. Furthermore, sustained growth and inflows can be achieved by controlling the GDP, and fiscal policies and by making and implementing fruitful policies. At the same time, different policy measures should be taken to attract different categories of capital inflows. 
Future studies can focus on the qualitative variables relating to regional competency and political stability, which may be more important in determining capital flows. Such variables should include judicial system, labour laws and the prevalence of corruption facilities. 


\section{References:}

Abdullah, M. A., Mansor, S. A. and Puah C. H., (2010), 'Determinants of International Capital Flows: The Case of Malaysia', Global Economy and Finance Journal Vol. 3 No.1, Pp. 31-43.

Amarasekara, C. (2004), 'Managing and Monitoring Direct and Portfolio Investment Flows: A Comparative Study of the SEACEN Countries', The SEACEN Centre, Kuala Lumpur, Malaysia

Arshad, M. U., Majeed, S. and Ali Shah, S. Z. (2012), 'The Determinants of Capital Inflow in Developing Economies: An Empirical Study of Pull Factors', Journal of Basic and Applied Scientific Research, 2(10) 9764-9769.

Bonizzi, B. (2013), 'Capital Flows to Emerging Markets: an Alternative Theoretical Framework', SOAS Department of Economics Working Paper Series, No. 186, The School of Oriental and African Studies.

Brana, S. and Lahet, D. (2008), 'Determinants of Capital Inflows into Asia : The Relevance of Contagion Effects as Push Factors', LAREFI Working Paper CR08$\mathrm{EFI} / 05$.

Broto, C., Diaz-Cassou, J. and Erce, A. (2011), 'Measuring and Explaining the Volatility of Capital Flows to Emerging Countries', Journal of Banking and Finance 35, Pp. 1941-1953

Celasun, O., Denizer, C. and He. D. (1999), 'Capital Flows, Macroeconomic Management and the Financial System: The Turkish Case, 1989-97', The World Bank Working Paper No. 2141.

Culha, A. A. (2006), 'Structural VAR Analysis of the Determinants of Capital Flows into Turkey', Central Bank Review, ISSN 1303-0701, Central Bank of the Republic of Turkey.

Chukwuemeka, E. P. (2008), 'Modelling the Long-run Determinants of Foreign Portfolio Investment in an Emerging Market: Evidence from Nigeria', International Conference on Applied Economics.

Dasgupta, D. and Ratha, D. (2000), 'What Factors Appear to Drive Private Capital Flows to Developing Countries? And How Does Official Lending Respond?', World Bank Policy Research Working Paper 2392.

Economic Progress of Independent Sri Lanka (1998), Central Bank of Sri Lanka.

Fernandez-Arias, E. and Montiel, P. J. (1996), 'The Surge in Capital Inflows to Developing Countries: An Analytical Overview', World Bank Economic Review 10: 51-77. 
Hernandez, L. and Rudolf, H. (1994), 'Domestic Factors, Sustainability and Soft Lending in the New Wave of Private Capital Inflows', The World Bank.

Hernandez, L., Mellado, P. and Valdes, R. (2001), 'Determinants of Private Capital Flows in the 1970s and 1990s: Is There Evidence of Contagion?', IMF Working Paper $\mathrm{WP} / 01 / 64$.

Husain, I. and Jun, K. W. (1992), 'Capital Flows to South Asian and ASEAN Countries: Trends, Determinants, and Policy Implications', Working Paper Series 842, World Bank

Jabbar, A. and Awan, A. G. (2014), 'The Determinants of Capital Inflow in Developing Countries with Special Reference to Pakistan', Developing Country Studies, ISSN 2224-607X (Paper) ISSN 2225-0565 (Online), Vol. 4, No.12, 2014.

Kara, S. U. (2007), 'The Determinants of Capital Flows: The Turkish Evidence'; METU, Ankara.

Kelegama, S. (2006), 'Development Under Stress, What Went Wrong?', Sage Publications, New Delhi.

Kim, Y. (2000), 'Causes of Capital Flows in Developing Countries', Journal of International Money and Finance, 19 pp. 235-253.

Mathema, S. R. (2004), 'Managing and Monitoring Direct and Portfolio Investment Flows: A Comparative Study of the SEACEN Countries', The SEACEN Centre, Kuala Lumpur, Malaysia.

Miguel, D. R. (2000), 'Foreign Direct Investment in Mexico: A Cointegration Analysis', Journal of Development Studies, Vol. (37), No. (1).

Obstfeld, M. and Rogoff, K. (1996), 'Foundation of International Macroeconomics', The MIT Press, England.

Perera, A. and Liyanage, E. (2011), 'An Empirical Investgation of the Twin Deficit Hyphothests: Evidence from Sri Lanka', Staff Studies, Central Bank of Sri Lanka, 41(1\&2), pp 41-88.

Pushparajah, P. (2009) 'Capital Flows and their Implications for Central Bank Policies in Sri Lanka'; The SEACEN Centre, Kualalumpur, Malaysia.

Ralhan, M. (2006), 'Determinants of Capital flows: A Cross-country Analysis', Econometrics Working Paper EWP0601, University of Victoria.

Rehman M. U., Arshad, Rehman S. U. and Muhammad I. (.....), 'Determinants of FDI', $2^{\text {nd }}$ International Conference on Business Management (ISBN: 978-969-9368-06-6). 
Rummel, O. (2014), 'Capital Flows and Exchange Rate Policies', 7th SEACENCCBS-BOE Advanced Course on Macroeconomic and Monetary Policy, Sri Lanka.

World Economic Outlook, October 2015, International Monetary Fund.

Yang, H., Xiong, Y. and Ze, Y. (2013), 'A Comparative Study of Determinants of International Capital Flows to Asian and Latin American Emerging Countries', Procedia Computer Science 17 ( 2013 ) 1258-1265.

Yu, H. Y. (2009), 'Capital Flows and their Implications for Central Bank Policies in Taiwan'. 


\section{Appendix I: Summary of the Empirical Evidence}

\begin{tabular}{|c|c|c|c|}
\hline Authors & Scope & Methodology & Key Findings \\
\hline $\begin{array}{l}\text { Abdullah M A, } \\
\text { Mansor S A } \\
\text { and Puah C H } \\
(2010)\end{array}$ & $\begin{array}{l}\text { Quarterly data of } \\
\text { Malaysia from 1985Q1 } \\
\text { to 2006Q4 for the } \\
\text { following variables } \\
\text { - Real GDP } \\
\text { - 3-month T-bill rate } \\
\text { - budget balance } \\
\text { - current account balance } \\
\text { - US industrial } \\
\text { production index } \\
\text { - world interest rate }\end{array}$ & $\begin{array}{l}\text { Johansen and } \\
\text { Juselius technique } \\
\text { to test long run } \\
\text { relationship } \\
\text { Error Correction } \\
\text { Model to detect the } \\
\text { long run } \\
\text { divergence from the } \\
\text { equilibrium } \\
\text { relationship } \\
\text { between the } \\
\text { explanatory } \\
\text { variables and capital } \\
\text { inflows }\end{array}$ & $\begin{array}{l}\text { BB and CAB appear to } \\
\text { be the most influential } \\
\text { variables in affecting } \\
\text { the inflows of capital } \\
\text { into Malaysia and GDP } \\
\text { and Industrial } \\
\text { countries' out put }\end{array}$ \\
\hline $\begin{array}{l}\text { Arshad, } \\
\text { Majeed \& Shah } \\
(2012)\end{array}$ & $\begin{array}{l}\text { Annual data of six } \\
\text { developing economies of } \\
\text { Asia from } 1990 \text { to } 2009 \\
\text { for the following } \\
\text { variables } \\
\text { - foreign reserves } \\
\text { - current account } \\
\text { - fiscal position } \\
\text { - GDP } \\
\text { - public debt }\end{array}$ & $\begin{array}{l}\text { Hausman } \\
\text { specification test } \\
\text { and fixed effects } \\
\text { model are used to } \\
\text { analyse the panel } \\
\text { data }\end{array}$ & $\begin{array}{l}\text { Empirical results show } \\
\text { that foreign reserves } \\
\text { and GDP positively } \\
\text { influence the capital } \\
\text { inflow, while the } \\
\text { current account has a } \\
\text { negative relation in } \\
\text { developing countries }\end{array}$ \\
\hline $\begin{array}{l}\text { Culha A A } \\
(2006)\end{array}$ & $\begin{array}{l}\text { Monthly data of Turkey } \\
\text { from 1992:01 to 2005:12 } \\
\text { for the following } \\
\text { variables } \\
\text { - 3-month US Treasury } \\
\text { bill } \\
\text { - US industrial } \\
\text { production index } \\
\text { - Turkish real Treasury } \\
\text { bill rate } \\
\text { - Istanbul stock exchange } \\
\text { price index } \\
\text { - budget balance } \\
\text { - current account balance }\end{array}$ & $\begin{array}{l}\text { Structural VAR to } \\
\text { identify the main } \\
\text { determinants of } \\
\text { capital inflows. } \\
\text { Impluse Response } \\
\text { Function and } \\
\text { Variance } \\
\text { Decomposition } \\
\text { Function are also } \\
\text { performed }\end{array}$ & $\begin{array}{l}\text { Empirical evidence } \\
\text { suggests that the } \\
\text { relative roles of some } \\
\text { of the factors have } \\
\text { changed considerably } \\
\text { in the post crisis period } \\
\text { and pull factors are } \\
\text { general dominant over } \\
\text { push factors in } \\
\text { determining capital } \\
\text { flows into Turkey }\end{array}$ \\
\hline $\begin{array}{l}\text { Hernandez, } \\
\text { Mellado \& } \\
\text { Valdes (2001) }\end{array}$ & $\begin{array}{l}\text { Annual data of } \\
\text { developing countries } \\
\text { from } 1977 \text { to } 1997 \text { for } \\
\text { the following variables }\end{array}$ & $\begin{array}{l}\text { Panel data analysis } \\
\text { was used }\end{array}$ & $\begin{array}{l}\text { Results show that } \\
\text { private capital flows are } \\
\text { determined mainly by a } \\
\text { country's own }\end{array}$ \\
\hline
\end{tabular}




\begin{tabular}{|c|c|c|c|}
\hline & $\begin{array}{l}\text { - US dollar 3-month - } \\
\text { LIBOR minus US CPI } \\
\text { - Net private capital } \\
\text { flows available to all } \\
\text { developing countries } \\
\text { minus flows received } \\
\text { by country } \\
\text { - GDP in industrial } \\
\text { countries } \\
\text { - real GDP growth } \\
\text { - budget balance } \\
\text { - Gross domestic } \\
\text { investment } \\
\text { - total exports } \\
\text { - foreign debt } \\
\text { - private sector credit } \\
\text { - real exchange rate }\end{array}$ & & $\begin{array}{l}\text { characteristic and } \\
\text { external factors are not } \\
\text { significant in } \\
\text { explaining the inflows }\end{array}$ \\
\hline Kara (2007) & $\begin{array}{l}\text { Monthly data of Turkey } \\
\text { from 1992:1 to } 2006: 4 \\
\text { for the following } \\
\text { variables } \\
\text { - Turkish ex-post real } \\
\text { interest rate } \\
\text { - real effective exchange } \\
\text { rate } \\
\text { - real income growth } \\
\text { - budget balance } \\
\text { - total central } \\
\text { government debt to } \\
\text { international reserves } \\
\text { - United States real } \\
\text { interest rate } \\
\text { - real income growth } \\
\text { - real interest rate }\end{array}$ & $\begin{array}{l}\text { Johansen } \\
\text { cointegration } \\
\text { analysis is } \\
\text { employed for } \\
\text { empirical } \\
\text { investigation }\end{array}$ & $\begin{array}{l}\text { Results show that } \\
\text { capital flows increase } \\
\text { in response to increases } \\
\text { in Turkish real interest } \\
\text { rate, real effective } \\
\text { exchange rate, real } \\
\text { GDP growth, budget } \\
\text { balance to GDP ratio, } \\
\text { and decreases in total } \\
\text { central government } \\
\text { debt to international } \\
\text { reserves ratio and the } \\
\text { US real interest rates. }\end{array}$ \\
\hline Kim Y (2000) & $\begin{array}{l}\text { Annual data of Mexico, } \\
\text { Chile, Korea, and } \\
\text { Malaysia for the } \\
\text { following variables } \\
\text { - terms of trade } \\
\text { - foreign output } \\
\text { - foreign interest rate } \\
\text { - domestic potential } \\
\text { output }\end{array}$ & $\begin{array}{l}\text { SVAR model to } \\
\text { investigate the } \\
\text { sources of capital } \\
\text { flows }\end{array}$ & $\begin{array}{l}\text { The results reveal that } \\
\text { the resurgence in } \\
\text { capital movements is } \\
\text { largely due to external } \\
\text { factors such as decrease } \\
\text { in the world interest } \\
\text { rate or recession in } \\
\text { industrial countries, } \\
\text { whereas domestic } \\
\text { factors including } \\
\text { country specific }\end{array}$ \\
\hline
\end{tabular}




\begin{tabular}{|c|c|c|c|}
\hline & $\begin{array}{l}\text { - domestic non-monetary } \\
\text { aggregate demand } \\
\text { - inflation } \\
\text { - domestic money }\end{array}$ & & $\begin{array}{l}\text { productivity shocks and } \\
\text { demand shocks are } \\
\text { relatively less } \\
\text { important. }\end{array}$ \\
\hline $\begin{array}{l}\text { Pushparajah P } \\
\text { (2007) }\end{array}$ & $\begin{array}{l}\text { Annual data of Sri Lanka } \\
\text { from } 1977 \text { to } 2007 \text { for } \\
\text { the following variables } \\
\text { - world real GDP growth } \\
\text { rate } \\
\text { - world real interest rate } \\
\text { (proxied by 1-Year US } \\
\text { \$ LIBOR rate) } \\
\text { - real GDP growth } \\
\text { - interest rate for fixed } \\
\text { deposit } \\
\text { - budget balance } \\
\text { - current account balance } \\
\text { - stock price } \\
\text { - exchange rate }\end{array}$ & $\begin{array}{l}\text { OLS-based } \\
\text { autoregressive } \\
\text { distributed lag } \\
\text { (ARDL) model is } \\
\text { adopted for } \\
\text { cointegration } \\
\text { analysis }\end{array}$ & $\begin{array}{l}\text { The long-run results } \\
\text { show that real GDP and } \\
\text { real interest rates are } \\
\text { positively associated } \\
\text { with capital inflows, } \\
\text { while world real GDP } \\
\text { is negatively associated } \\
\text { with capital flows. }\end{array}$ \\
\hline Ralhan (2006) & $\begin{array}{l}\text { Annual data for the } \\
\text { following variables } \\
\text { - London Inter-bank } \\
\text { Offered Rate } \\
\text { - rate of inflation } \\
\text { - total external debt } \\
\text { - GDP } \\
\text { - gross fiscal deficit } \\
\text { - gross foreign exchange } \\
\text { reserves } \\
\text { - degree of openness of } \\
\text { the economy }\end{array}$ & $\begin{array}{l}\text { Conventional } \\
\text { approach and } \\
\text { Non-linear } \\
\text { Seemingly } \\
\text { Unrelated } \\
\text { Regression } \\
\text { estimation are used }\end{array}$ & $\begin{array}{l}\text { Results reveal that } \\
\text { gross foreign reserves } \\
\text { are one of the most } \\
\text { important factors } \\
\text { affecting capital flows } \\
\text { in all of the countries } \\
\text { considered, regardless } \\
\text { of any region or group. } \\
\text { The level of gross } \\
\text { domestic product is } \\
\text { another factor } \\
\text { influencing capital } \\
\text { flows and growth in the } \\
\text { size of an economy can } \\
\text { lead to an increase in } \\
\text { capital flows because of } \\
\text { growing investors' } \\
\text { confidence. }\end{array}$ \\
\hline
\end{tabular}




\section{Appendix II: Robustness Check (Alternative models)}

In order to check the robustness of the results the following alternative models were analysed.

\begin{tabular}{|c|c|c|}
\hline Variable & Model 1 & Model 2 \\
\hline Constant & $\begin{array}{r}-12.247 \\
-2.638\end{array}$ & $\begin{array}{l}0.928288 \\
{[0.5887]}\end{array}$ \\
\hline Log Real GDP & & $\begin{array}{c}0.20102 \\
{[1.9091]^{*}}\end{array}$ \\
\hline Industrial Production Index & $\begin{array}{l}0.0042 \\
{[2.3314]^{* *}}\end{array}$ & \\
\hline Budget Balance & $\begin{array}{l}-0.000519 \\
{[-3.3015]^{* * *}}\end{array}$ & \\
\hline Government Revenue & & $\begin{array}{c}2.67 \mathrm{E}-07 \\
{[1.9879]^{* *}}\end{array}$ \\
\hline Current Account Balance & $\begin{array}{l}-0.0002 \\
-1.0763\end{array}$ & $\begin{array}{l}-0.0002 \\
-1.3551\end{array}$ \\
\hline Interest Rate Differential & $\begin{array}{c}0.0942 \\
{[-2.1091]^{* *}}\end{array}$ & $\begin{array}{l}0.1614 \\
{[2.2956]^{* *}}\end{array}$ \\
\hline Credit to Private Sector & $\begin{array}{c}0.0043 \\
{[0.8504]}\end{array}$ & $\begin{array}{l}0.007745 \\
{[1.3622]}\end{array}$ \\
\hline $\begin{array}{l}\text { Industrial Production Index of } \\
\text { Advanced Economies }\end{array}$ & $\begin{array}{l}0.03536 \\
{[2.9839]^{* * *}}\end{array}$ & $\begin{array}{c}0.03482 \\
{[2.5301]^{* *}}\end{array}$ \\
\hline Dummy variable for Civil War & $\begin{array}{c}-0.48926 \\
{[-2.3286]^{* *}}\end{array}$ & $\begin{array}{l}-0.5255 \\
{[-2.2205]^{* *}}\end{array}$ \\
\hline $\begin{array}{l}\text { Number of Observations } \\
\text { R-squared }\end{array}$ & $\begin{array}{r}58 \\
0.762 \\
\end{array}$ & $\begin{array}{r}58 \\
0.755 \\
\end{array}$ \\
\hline
\end{tabular}

t-statistics are in square brackets

* Significant at $10 \% \quad * *$ Significant at $5 \% \quad * * *$ Significant at $1 \%$ 